\title{
Medical Devices and Diagnostic Engineering
}

\section{Opinion}

\section{Dementia testimony}

\author{
Nick Kostovic* \\ Bio Technological Health Center, Inc., 3838 Carson Street, Suite 307, Torrance, CA 90503, Los Angeles, USA
}

My name is Leslee Cook, I am a psychotherapist who specializes in working with people who have PTSD and anxiety. I had a Traumatic Brain Injury (TBI) at the age of 13yo. Then in 2003 at the age of 50 I was in a head-on car collision and suffered another TBI. By 2008 I started to realize that my memory was becoming problematic so in 2009 I retired early from my full time job at a local community college to open my part-time private practice.

I met Nick Kostovic Nov. 2014 and started working with him. By the time I saw him I was considering completely stopping my work as my memory was such a challenge. I couldn't hold in my memory two digits of a phone number from the page to enter my cell phone. It was very embarrassing when I couldn't remember names and nor recognize faces of people I had met briefly before. I had always prided myself with being able to remember faces even of junior high school classmates.

My memory was so frustrating just standing up from what I was doing as I would walk away from my desk I would completely forget what I had decided I needed to do. I didn't get it checked out with a doctor as I didn't need any diagnosis I was experiencing this growing dementia and I knew it was getting worse. It was so scary, I was easily confused and could no longer follow verbal details, I had to write everything down. These daily debilitating experiences made me think that I should stop working and make plans to move out of state to live near my sister who could take care of me. I was afraid that shortly I could no longer skillfully handle all everyday tasks of paying bills on time, writing invoices and other responsibilities.

I worked with the KBTE medical laser first three times a week each time was a double session. Then after 8 months I started receiving the treatment twice a week always a double session. Now I get a double session treatment once a week. At first it was very very painful each spot that Nick worked on with his fingers. He would also use the biological agents and that was extremely painful. But Nick began at the lowest frequencies of 2-10 Nano amperes. If the pain was too great I could always take my hand off of the moist pad, so I was always in control.

After 4 months the pain was not as intense but still it was painful when the laser acupuncture found a painful spot and would burned away the dead oxidized proteins which naturally had built up for 50 years, but there were more holes in my gray matter due to the problems caused by the two concussions. Nick explained that everyone has dead cells that build up because hundreds of brain cells die each day but the body can't naturally excrete them as fast as they are dying so they pile up and prevent the oxygen rich blood from reaching the tissue.

Have you ever gone into a care facility for the elderly? There is a distinct smell well this isn't because the outside of the bodies aren't clean. No, as Nick explains it, it is the stock piles of dead cells that the body has never before been able to excrete until the discovery of the KBTE device. Not only can Nick burn away the unhealthy cells that were growing but with his device he can attract biophotons which can awaken the hibernating brain cells. Of course I never even imagined that the $90 \%$ of gray matter could be awakened from hibernation. But Nick studied and figured out how to gently awaken these brain nerve cells.

In the Final Segment of Nick's process which awakens these hibernating brain cells Nick puts his two index fingers on my forehead/ eyebrows. This never hurts, at first I saw with my eyes closed colors, red, blue, white, black. But after approx 8 months or so I saw a rotating semi circle with a white background circle with three smaller circles containing fast moving black dots inside the three smaller circles.

Then approx 11 months later the circle was fully formed. Nick explained this showed him that areas of the brain that we had just been working on are now healed. This part of the treatment always felt good but was gratifying to see the full circle instead of the semi circle, and to understand what it actually meant.

I've had headaches always in the right temporal zone(which is the side I had the concussion when the right side of my head hit the window during the car collision). This area Nick worked on gently and extensively and after 8 months the pressure and pain from the device is gone. I never got a headache during the treatment and now I never get anymore headaches.

It took only 4 months before I knew that my dementia was not progressing. After 6 months my depression had finally lifted and I could feel that I was starting to have better recall. After 8 months I could recall names with better ease. After 10 months I started to recall childhood memories. It is now 19 months since we started, I read more quickly and can recall what I've read which is a such a great relief. I feel so grateful to have found Nick Kostovic and his KBTE medical laser device.

This advanced unparalleled treatment modality has given me back a functioning memory, I feel so much more confident and certain that my memory is no longer declining and is improving daily. I am able to see more clients and can confidently perform my work.

I felt so excited about the possibilities of Nick's device that I have recommended it to my friends who also have received great benefits. I knew Nick was frustrated with the slowness of the FDA and was considering leaving America to work with the Chinese government which has expressed eagerness for him to bring his innovations to Beijing. So I decided to spend one day a week networking to help him

Correspondence to: Nick Kostovic, Bio Technological Health Center, Inc., 3838 Carson Street, Suite 307, Torrance, CA 90503, Los Angeles, USA, Tel: +1-310543-0309/+1-310-381-9105; Fax: +1-310-540-6946; E-mail: nick@kbhealthcenter.com

Received: November 10, 2016; Accepted: November 18, 2016; Published: November 23, 2016 
to meet with "open minded far reaching thinkers" such as Richard Branson and Elon Musk. I believe Nick Kostovic will one day receive the Nobel Prize in Medicine for the greatest discovery of the 21st Century!

The KBTE device not only stops cancer but can heal any other ailing organs given enough time to cleanse the body of oxidized cells and plaque and then heal the ailing organ. I even had him work on a bit of skin damage from the sun on the top of my ear, which the dermatologist had removed multiple times but it kept returning. He also worked on ridding my body of Osteoporosis but I won't go into depth with that here.
I feel so lucky to have my neo-cortex functioning again, there is no medical treatment on this planet that could have stopped my progressing dementia except the KBTE device. Modern science has medicine for dementia but they admit they can only slow it down certainly not stops it or turn it around. I'm so grateful that Nick can awaken those hibernating brain cells (most of us only use 3-10\% of that gray matter) who knew the dormant brain cells could be awakened.

Leslee Cook,MFT,SEP,NARM

310-617-2577

Copyright: $@ 2016$ Kostovic N. This is an open-access article distributed under the terms of the Creative Commons Attribution License, which permits unrestricted use, distribution, and reproduction in any medium, provided the original author and source are credited. 